\title{
Satellite observations of unprecedented phytoplankton blooms in the Maud Rise polynya, Southern Ocean
}

\author{
Babula Jena and Anilkumar N. Pillai \\ ESSO - National Centre for Polar and Ocean Research, Ministry of Earth Sciences, \\ Government of India, Vasco da Gama, India \\ Correspondence: Babula Jena (bjena@ncpor.res.in)
}

Received: 19 November 2019 - Discussion started: 11 December 2019

Revised: 21 March 2020 - Accepted: 25 March 2020 - Published: 24 April 2020

\begin{abstract}
The appearance of phytoplankton blooms within sea ice cover is of high importance considering the upper ocean primary production that controls the biological pump, with implications for atmospheric $\mathrm{CO}_{2}$ and global climate. Satellite-derived chlorophyll $a$ concentration showed unprecedented phytoplankton blooms in the Maud Rise polynya, Southern Ocean, with chlorophyll $a$ reaching up to $4.67 \mathrm{mg} \mathrm{m}^{-3}$ during 2017. Multi-satellite data indicated that the bloom appeared for the first time since the entire mission records started in 1978. An Argo float located in the polynya edge provided evidence of bloom conditions in austral spring 2017 (chlorophyll $a$ up to $5.47 \mathrm{mg} \mathrm{m}^{-3}$ ) compared to the preceding years with prevailing low chlorophyll $a$. The occurrence of bloom was associated with the supply of nutrients into the upper ocean through Ekman upwelling (driven by wind stress curl and cyclonic ocean eddies) and improved light conditions of up to 61.9 einstein $\mathrm{m}^{-2} \mathrm{~d}^{-1}$. The net primary production from the Aqua Moderate Resolution Imaging Spectroradiometer chlorophyll-based algorithm showed that the Maud Rise polynya was as productive as the Antarctic coastal polynyas, with carbon fixation rates reaching up to $415.08 \mathrm{mg} \mathrm{C} \mathrm{m}^{-2} \mathrm{~d}^{-1}$. The study demonstrates how the phytoplankton in the Southern Ocean (specifically over the shallow bathymetric region) would likely respond in the future under warming climate conditions and continued melting of Antarctic sea ice.
\end{abstract}

\section{Introduction}

Antarctica sea ice moderately increased during the satellite era from 1979 to 2015, with regional heterogeneity that com- prises both increasing and decreasing patterns in different sectors (Turner et al., 2017). However, anomalously record low sea ice extent and area were observed for three successive years from 2016 to 2018 with the maximum melting occurring in 2017 (Parkinson, 2019). Amid the pronounced melting, the largest and most prolonged Maud Rise (MR) open ocean polynya since the 1970 s reappeared on 14 September $2017\left(\sim 9.3 \times 10^{3} \mathrm{~km}^{2}\right)$ and expanded to a maximum on 1 December $2017\left(\sim 298.1 \times 10^{3} \mathrm{~km}^{2}\right)$ and existed for $79 \mathrm{~d}$ (Jena et al., 2019). Appearance of the polynyas plays an important role in the oceanic phytoplankton and primary production that control the biological pump of the ocean (Arrigo and Dijken, 2003; Shadwick et al., 2017), as well as being important for marine mammals and birds (Labrousse et al., 2018; Stirling, 1997), global heat and salt fluxes (Tamura et al., 2008), Antarctic bottom water properties (Zanowski et al., 2015), and atmospheric circulation (Weijer et al., 2017). However, due to their spatial dimension, the polynyas are generally not represented well in large-scale climate models, limiting the capability of simulating and projecting polynya-related biophysical changes under a future climate change scenario (Li et al., 2016).

The Southern Ocean (SO) is known as the largest highnutrient low-chlorophyll (HNLC) area of the global ocean. For the past 50 years, the loss of ice shelves and glacier retreat around the Antarctic Peninsula have increased, and at least $24000 \mathrm{~km}^{2}$ in surface area of new open water was rapidly colonized by new phytoplankton blooms, with new benthic and marine zooplankton communities in the SO (Peck et al., 2010). In the background of HNLC, the occurrence of polynyas can enhance the chlorophyll $a(\mathrm{chl} a)$ concentration (a proxy for phytoplankton biomass) due to the in- 
crease in surface area of new open waters and growth season of the phytoplankton (Kahru et al., 2016). The bloom occurrence in the SO has been linked with oceanographic features such as jet streams, meanders, and mesoscale eddies, which can lead to increased iron and silicate supply by the ocean upwelling (Strass et al., 2002), thereby improving co-limitation of nutrient and light for phytoplankton growth (Hoppe et al., 2017). Oceanic eddies have been found to regulate chl $a$ variability in the SO, with higher (lower) values observed for the cyclonic (anticyclones) eddies (Kahru et al., 2007). The polynyas of the Amundsen and Ross seas have high primary productivity that contributes to the $\mathrm{SO}$ carbon dioxide $\left(\mathrm{CO}_{2}\right)$ sink (Alderkamp et al., 2012; Arrigo et al., 2008a; Arrigo and Alderkamp, 2012; Yager et al., 2012). The primary productivity of these regions reaches up to $3 \mathrm{~g} \mathrm{C} \mathrm{m}^{-2} \mathrm{~d}^{-1}$, roughly 10 -fold more than the SO mean productivity (Arrigo and Dijken, 2003). The high productivity values in the polynya have been attributed to the supply of iron from the upwelling of iron-rich deep water (Planquette et al., 2013), sediment diffusion or resuspension followed by upwelling (Ardelan et al., 2010), atmospheric inputs (Cassar et al., 2007; Wagener et al., 2008), melting of sea ice (Lannuzel et al., 2010; van der Merwe et al., 2011), iceberg-delivered glacial debris (Raiswell et al., 2008), and melting of ice shelves (Pritchard et al., 2009; Wåhlin et al., 2010). The Amundsen polynya is one of the productive polynyas of Antarctica with satellitederived chl $a\left(2.2 \mathrm{mg} \mathrm{m}^{-3}\right) 40 \%$ greater than in the Ross Sea polynya (1.5 $\mathrm{mg} \mathrm{m}^{-3}$ ) (Schofield et al., 2015). Although the polynyas are believed to be the sites of phytoplankton blooms in spring (Arrigo and Dijken, 2003), and they act as sinks of atmospheric $\mathrm{CO}_{2}$ because of both physical-chemical processes and biological activity (Bates et al., 1998; Mu et al., 2014), very little is known about the MR polynya due to its rare appearance. In this paper, we report the first evidence of the occurrence of phytoplankton bloom in the MR polynya from satellite-derived ocean color data and the Argo float. Further, the role of physical processes in the occurrence of bloom in the polynya is examined using relevant physical oceanographic data, followed by bloom occurrence's likely implication for ocean-atmosphere exchange of $\mathrm{CO}_{2}$.

\section{Materials and methods}

In order to understand the impact of bathymetry on the phytoplankton biomass, the MR seamount was mapped using bathymetric raster data $(21601 \times 10801$ pixels $)$ from the Earth Topography One Arc-Minute Global Relief Model, 2009 (ETOPO1) (https://www.ngdc.noaa.gov/, last access: 21 March 2020). The raster data were converted to polyline features with a contour interval of $500 \mathrm{~m}$ for showing the extent of the seamount (Fig. 1a). A level-3 monthly composite of satellite-derived near-surface chl $a$ imageries from the Nimbus-7 Coastal Zone Color Scanner (CZCS), Sea-viewing Wide Field-of-view Sensor (SeaWiFS), Aqua Moderate Res- olution Imaging Spectroradiometer (Aqua MODIS), and Visible Infrared Imaging Radiometer Suite (VIIRS) were used, as per the availability of data from 1978 to 2017 (Fig. 1b-e). Level-2 Aqua MODIS ascending passes were processed (relatively cloud-free data) to generate the highspatial-resolution $(\sim 1 \mathrm{~km})$ chl $a$ images on 25 October (14:45 UTC), 6 November (15:05 UTC), and 21 November 2017 (14:25 UTC) (Fig. 2). We used a standard chl $a$ retrieving algorithm that uses a combination of both lower and higher ranges of chl $a$ retrieval as described in the Algorithm Theoretical Basis Document (ATBD) from the NASA Earth Observing System Project Science Office (https://oceancolor. gsfc.nasa.gov/atbd/chlor_a/, last access: 21 March 2020). In this study, we have used the criteria of chl $a>0.8 \mathrm{mg} \mathrm{m}^{-3}$ (Fitch and Moore, 2007) for defining a phytoplankton bloom after considering the underestimation tendency of chl $a$ measurement from satellite observations over the Southern Ocean (Jena, 2017).

In order to analyze the Aqua-MODIS-derived net primary production (NPP), we have validated three ocean-colorbased models such as the vertically generalized production model (VGPM), Eppley-VGPM, and carbon-based productivity model (CbPM) for selecting the best model for the study region. We evaluated the performance of these models by comparing with the in situ NPP estimated using ${ }^{13} \mathrm{C}$ tracer during the Indian scientific expedition to the Southern Ocean in 2009. The locations of in situ NPP observations during the austral summer (February to April 2009) are presented in Fig. 3a. The in situ NPP from 11 observations ranges from about 85.04 to $923.83 \mathrm{mg} \mathrm{C} \mathrm{m}^{-2} \mathrm{~d}^{-1}$. The detailed method of ${ }^{13} \mathrm{C}$ measurement was documented in previous work (Gandhi et al., 2012). The VGPM was developed to estimate the NPP from chlorophyll concentration after considering the influence of temperature on the efficiency of chlorophyll-specific photosynthesis. (Behrenfeld and Falkowski, 1997b). The Eppley-VGPM makes use of an exponential function developed from changes in growth rates of phytoplankton over varied temperature ranges for a wide variety of species (Eppley, 1972). Further, a new CbPM model was developed that uses backscattering coefficients and chlorophyll-to-carbon ratios for estimation of phytoplankton carbon biomass and phytoplankton growth rates, respectively (Westberry et al., 2008). The model-based NPP values were available on a weekly timescale with a spatial resolution of $\sim 4 \mathrm{~km}$. The pixel values from the models were extracted around each in situ observation of NPP to generate the matchups for the validation strategy, a method adopted by several authors (Jena, 2017; Johnson et al., 2013). The comparative statistical analysis suggested that the scatters were much better in the case of Eppley-VGPM-estimated NPP (Fig. 3c) than those in the case of VGPM (Fig. 3b) and CbPM (Fig. 3d). A bias of $-26.21 \mathrm{mg} \mathrm{C} \mathrm{m}^{-2} \mathrm{~d}^{-1}$ for the Eppley-VGPM-obtained NPP value was much better than that obtained from the VGPM (bias $=104.40 \mathrm{mg} \mathrm{C} \mathrm{m}^{-2} \mathrm{~d}^{-1}$ ) and CbPM (bias $=94.14 \mathrm{mg} \mathrm{C} \mathrm{m}^{-2} \mathrm{~d}^{-1}$ ) (Table 1). The NPP 
Table 1. Validation of ocean-color-based models (VGPM, EppleyVGPM, and (bPM) with in situ net primary production ( $\mathrm{mg} \mathrm{C} \mathrm{m}{ }^{-2} \mathrm{~d}^{-1}$ ) estimated using ${ }^{13} \mathrm{C}$ tracer during the scientific expeditions to the Southern Ocean in 2009. CbPM: carbon-based productivity model; VGPM: vertically generalized production model.

\begin{tabular}{lrrrr}
\hline & $\begin{array}{r}r \text { (coefficient } \\
\text { of correlation) }\end{array}$ & $\begin{array}{r}\text { Standard } \\
\text { error }\end{array}$ & Bias & $p$ value \\
\hline VGPM & 0.82 & 203.69 & 104.40 & 0.001 \\
Eppley-VGPM & 0.82 & 116.16 & -26.21 & 0.001 \\
CbPM & 0.66 & 142.84 & 94.14 & 0.026 \\
\hline
\end{tabular}

values from VGPM and CbPM indicated significant overestimations. The coefficient of correlation $(r)$ and standard error (SE) for Eppley-VGPM NPP values $(r=0.82$ and $\mathrm{SE}=116.16 \mathrm{mg} \mathrm{C} \mathrm{m}^{-2} \mathrm{~d}^{-1}$ ) were better than those obtained from the VGPM $\left(r=0.82\right.$ and $\left.\mathrm{SE}=203.69 \mathrm{mg} \mathrm{C} \mathrm{m}^{-2} \mathrm{~d}^{-1}\right)$ and $\mathrm{CbPM}\left(r=0.66\right.$ and $\left.\mathrm{SE}=142.84 \mathrm{mg} \mathrm{C} \mathrm{m}^{-2} \mathrm{~d}^{-1}\right)$. Results suggested the Eppley-VGPM-based NPP values match reasonably well with the in situ NPP. Therefore, we used the Eppley-VGPM model for the present study, taking Aqua MODIS as the input.

We used monthly sea ice concentration (SIC) data (September to November 2017) from the Special Sensor Microwave Imager/Sounder (SSMIS) with spatial resolution of $25 \mathrm{~km}$ acquired from the National Snow and Ice Data Center (NSIDC) (data ID G02135, version 3). The data were generated using the NASA Team algorithm, which converts satellite-derived brightness temperatures to gridded SIC (Cavalieri et al., 1997). A detailed description of the sensor characteristics, sea ice processing methods, synoptic coverage, resolution, projection, and validation of sea ice retrieval from passive microwave sensors is given in earlier work (Fetterer et al., 2016). The polynya was assumed when the pixel values were found to be less than or equal to $15 \%$ of SIC (Fig. 4a-c) (Jena et al., 2019). In order to examine the role of oceanic processes in the formation of the phytoplankton bloom in the polynya, we used relevant physical oceanographic data. Metop Advanced SCATterometer (ASCAT) wind stress curl and Ekman upwelling data (Pond and Pickard, 1983) were acquired from the National Oceanic and Atmospheric Administration (NOAA) Coast watch (https: //coastwatch.pfeg.noaa.gov, last access: 21 March 2020) at a spatial resolution of $0.25^{\circ} \times 0.25^{\circ}$ (Fig. $4 \mathrm{~g}-1$ ). Oceanic eddies were identified from the sea surface height anomaly (SSHA) and geostrophic currents $\left(0.25^{\circ} \times 0.25^{\circ}\right)$ derived from multi-mission merged satellite altimeter data (https: //las.aviso.altimetry.fr/, last access: 21 March 2020) (Fig. 4df) (Jena et al., 2019). Although the dipole structure of cyclonic and anticyclonic eddies was observed in the MR polynya, cyclonic eddies dominated the flow pattern in the region during the event. Therefore, we focused on the cyclonic eddies because they can upwell the deep, warm and nutrientrich water to the upper ocean for $\operatorname{chl} a$ enhancement. The optimal interpolated sea surface temperature (OI SST) data $(9 \mathrm{~km} \times 9 \mathrm{~km})$ were obtained from Remote Sensing Systems (http://www.remss.com/, last access: 21 March 2020) and were produced after merging the microwave (cloud penetration capabilities) and infrared SST (high spatial resolution) using an OI scheme (Reynolds and Smith, 1994) (Fig. 4mo). In order to understand the vertical structures of biophysical parameters, we used Argo float (ID-5904468) data that had remained in the MR polynya from 2015 to 2017 (http: //www.argo.ucsd.edu/, last access: 21 March 2020) (Fig. 1a). The Argo-based partial pressure of $\mathrm{CO}_{2}\left(p \mathrm{CO}_{2}\right)$ in the water column was calculated from a Deep-Sea DuraFET $\mathrm{pH}$ sensor after using an existing algorithm for total alkalinity (Johnson et al., 2016). The uncertainty in the derived value is about $11 \mu$ atm at $p \mathrm{CO}_{2}$ of $400 \mu \mathrm{atm}(\sim 2.7 \%)$, considering the combined contribution from the $\mathrm{pH}$ sensor, the alkalinity estimate, and carbonate system equilibrium constants (Williams et al., 2017). The monthly net shortwave radiation was acquired from the European Centre for Medium-Range Weather Forecasts (ECMWF) (grid resolution of $0.25^{\circ}$ ) during January 1979-December 2017. Monthly anomalies of shortwave radiation for September-November 2017 were computed relative to a 38-year climatology (1979-2016).

\section{Results and discussion}

\subsection{Phytoplankton bloom within the polynya}

Although a large polynya was formed within the MR sea ice cover during September 2017, no phytoplankton bloom is observed in the satellite record. The polynya extent was nearly static from September to October and accompanied by a small patch of bloom (chl $a$ up to $3.48 \mathrm{mg} \mathrm{m}^{-3}$ ) centered at $3.77^{\circ} \mathrm{E}$ and $64.72^{\circ} \mathrm{S}$ (Figs. $1 \mathrm{~b}$; $4 \mathrm{~b}$ ), which remains otherwise covered by the sea ice. Prior to the October 2017 event, no chl $a$ was observed for the month of October from 1978 to 2016 even after considering the entire data records of CZCS, SeaWiFS, Aqua MODIS, and VIIRS. During November 2017, the polynya was enlarged and shifted southeastward with high chl $a$ concentration reaching up to $4.66 \mathrm{mg} \mathrm{m}^{-3}$ (Figs. 1c; 4c). The bloom was formed approximately between $64.5-66.5^{\circ} \mathrm{S}$ and $4-8^{\circ} \mathrm{E}$. Prior to the November 2017 event, satellite-derived chl $a$ observations were scarce (SeaWiFS and MODIS) and missing (CZCS and VIIRS) for the month of November from 1978 to 2016. Figure $1 \mathrm{~d}$ and e show the climatological composite of chl $a$ observations in November for Aqua MODIS (2002-2016) and SeaWiFS (1997-2010), respectively. The scarce and missing observations were mainly due to the presence of seasonal sea ice cover and cloud cover in the MR. The result suggests that the observed bloom from October to November 2017 had appeared for the first time within the MR polynya in the records of satellite observations since 1978 (Fig. 1b-c). Even though the monthly composite im- 

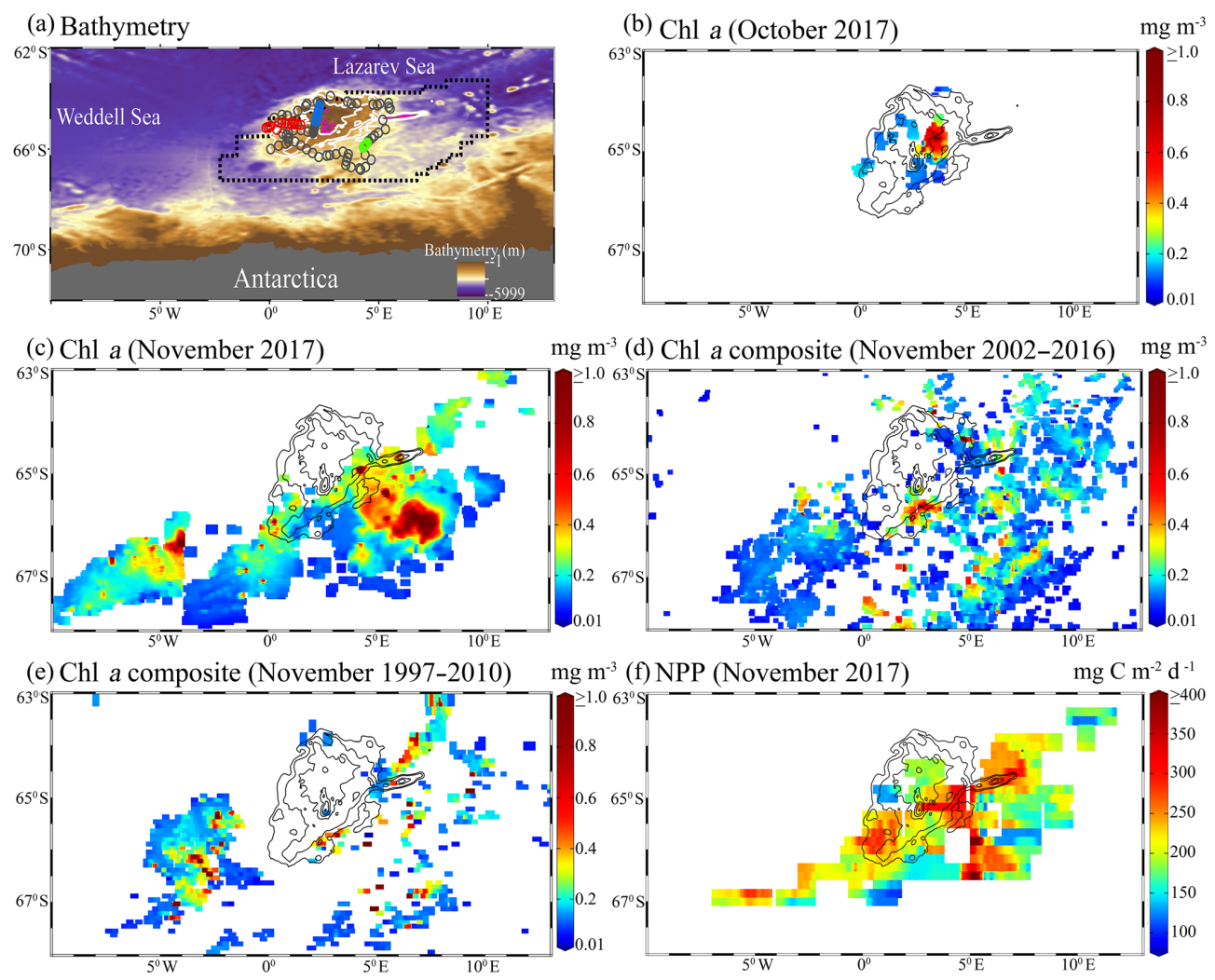

Figure 1. (a) Bathymetry map of the Maud Rise from the Earth Topography One Arc-Minute Global Relief Model, 2009. Pink lines show the depth contours shallower than $2000 \mathrm{~m}$, and other white contours are spaced by $500 \mathrm{~m}$ with deeper values. The dashed polygon shows the extent of the polynya on 21 November 2017. Circles represents the location of an ARGO float (ID-5904468) from 19 January 2015 to 18 March 2018. Red, green, and blue circles show the float location from August to December for 2017, 2016, and 2015, respectively. (b) Monthly mean chlorophyll $a$ (chl $a$ ) from the Aqua Moderate Resolution Imaging Spectroradiometer (Aqua MODIS) during October 2017. (c) Monthly mean chl $a$ from Aqua MODIS during November 2017. (d) Long-term composite of Aqua MODIS chl $a$ (2002-2016) for November. (e) Long-term composite of SeaWiFS chl a (1997-2010) for November. (f) Monthly mean daily net primary productivity (NPP) computed from the Eppley vertically generalized production model for November 2017. The polyline features in (b-f) show the extent of the Maud Rise seamount with a contour interval of $500 \mathrm{~m}$.

ages show the evidence of blooms, we processed level2 high-spatial-resolution scenes of Aqua MODIS that provided more information on this unprecedented phytoplankton bloom. Several selected scenes that have relatively better coverage showed a patch of bloom on 25 October, followed by a wide band of bloom on 6 and 21 November 2017 (Fig. 2). The chl $a$ values reached as high as $4.67 \mathrm{mg} \mathrm{m}^{-3}$ on 6 November 2017 (Fig. 2b). A high diffuse attenuation coefficient (Kd 490) of up to 0.39 and $0.37 \mathrm{~m}^{-1}$ was observed during October and November, respectively, which is an indicator of sediment resuspension and bloom conditions in the MR polynya (Table 2). The previously reported highest chl $a$ concentration in the Antarctic polynya was identified in the Amundsen Sea (coastal polynya) with values reaching about $6.98 \mathrm{mg} \mathrm{m}^{-3}$ (Arrigo and Dijken, 2003). The bloom in the MR polynya was also tracked by a robotic Argo float (ID5904468) that had remained at the northwestern edge of the polynya (Figs. 1a; 5a). Results show enhanced chl $a$ values from September to November 2017. The bloom condition was initiated on 25 October 2017 with chl $a$ maxima of up to $1.27 \mathrm{mg} \mathrm{m}^{-3}$ (36 m depth) at $0.86^{\circ} \mathrm{E}$ and $64.98^{\circ} \mathrm{S}$ (Fig. 5a). The chl $a$ value reached up to $1.31 \mathrm{mg} \mathrm{m}^{-3}$ (41 $\mathrm{m}$ depth) and $1.73 \mathrm{mg} \mathrm{m}^{-3}$ (36 m depth), respectively on 4 and 14 November 2017. Further, on 24 November 2017, the values reached as high as $5.47 \mathrm{mg} \mathrm{m}^{-3}(11 \mathrm{~m} \mathrm{depth})$ at $1.43^{\circ} \mathrm{E}$ and $65.04^{\circ} \mathrm{S}$. In order to check whether this observed bloom is a seasonal or an episodic feature of the MR, we analyzed the Argo float data during the 2 preceding years of 2015 and 2016 when the sea ice was covered. Analysis shows that the bloom was absent and the chl $a$ value found to be rather low during October and November for 2015 and 2016 (Fig. 5b, c). Thus, the result confirms that the observed bloom in 2017 was an unprecedented feature considering both the Argo float and multi-sensor satellite data. 

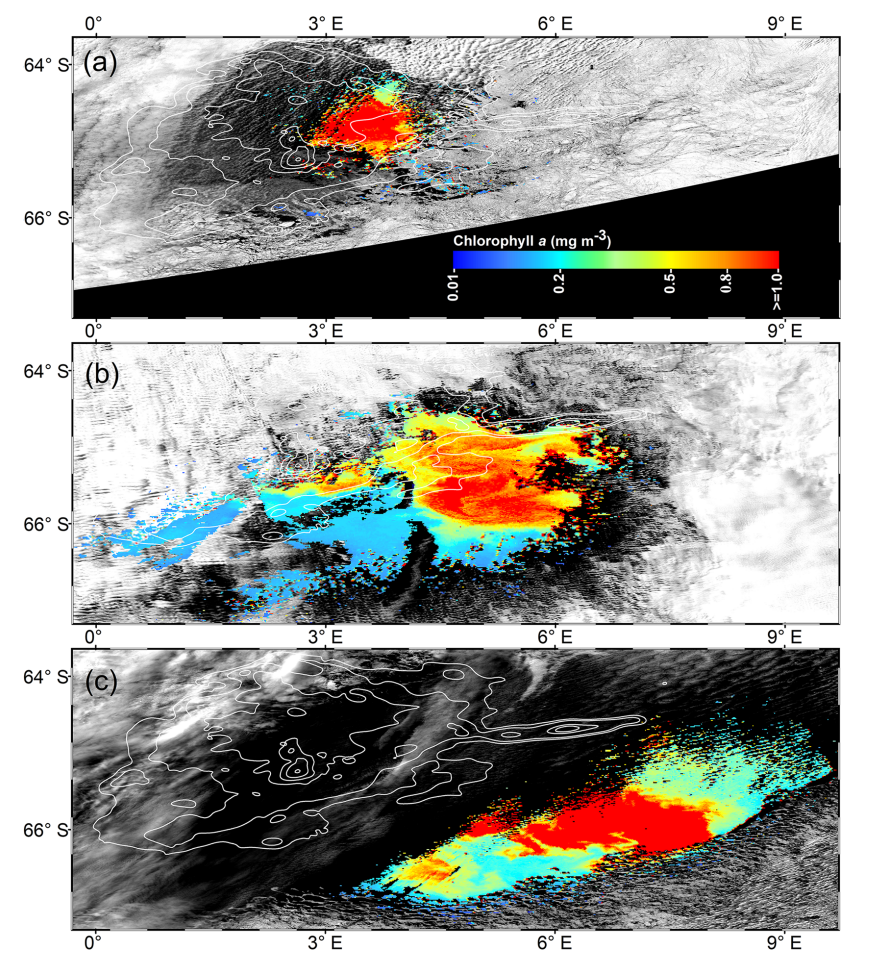

Figure 2. High-spatial-resolution $(\sim 1 \mathrm{~km})$ Aqua MODIS ascending passes on (a) 25 October (14:45), (b) 6 November (15:05), and (c) 21 November 2017 (14:25), showing the unprecedented phytoplankton blooms in the Maud Rise polynya. The white contours show the extent of the Maud Rise seamount.

\subsection{Causes of the observed bloom formation}

Generally, the phytoplankton biomass remains low in the SO, which is mainly ascribed to the lack of micronutrient iron apart from strong zooplankton grazing pressure and light and silicate limitation (de Baar and Boyd, 1999; Boyd et al., 2001; Gall et al., 2001; Selph et al., 2001). The input of ironenriched atmospheric dust from the continents to the SO is the lowest in the world's oceans (Duce and Tindale, 1991). The oceanic sources of iron from the deep water and vertical diffusion of iron through the water column have been reported as likely pathways of iron supply to the upper ocean (Jena, 2016; Tagliabue et al., 2014). The occurrence of phytoplankton bloom is possible over the shallow regions of the MR seamount where the doming of the isotherm/isopycnal can bring deeper high-nutrient water above the seamount, where it may be utilized with a conducive environment of light availability and water column stability (White and Mohn, 2002). Analysis of bathymetric data indicated the peak of the MR seamount is located at $65.23^{\circ} \mathrm{S}, 2.63^{\circ} \mathrm{E}$ and rises from the abyssal plain of $\sim 5200 \mathrm{~m}$ to the shallowest depth of $\sim 968 \mathrm{~m}$ (Fig. 1a), influencing the local upliftment of thermocline and nutrient-enriched deep water (Jena et al., 2019; Mashayek et al., 2017; Muench et al., 2001; Roden, 2013). The oceanic processes that can bring subsurface nu-
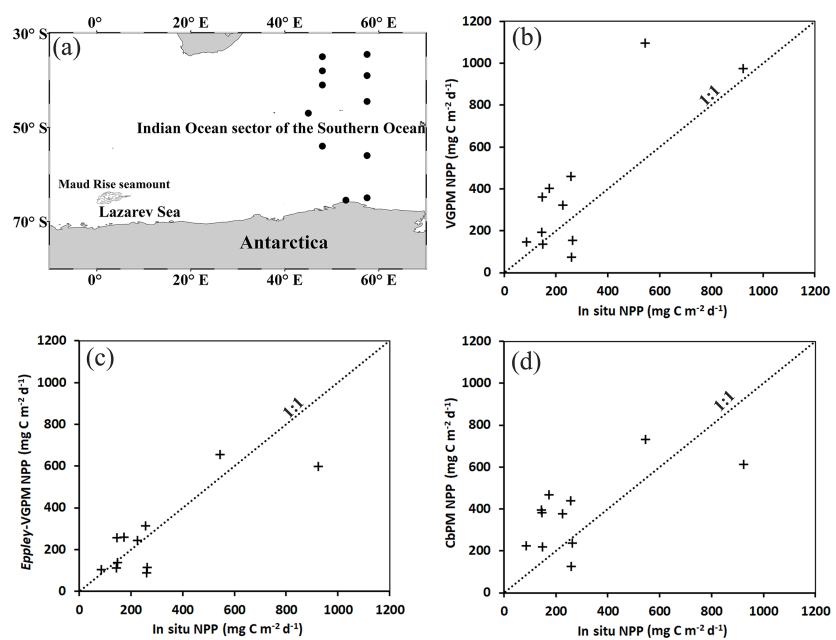

Figure 3. (a) Circles showing the locations of in situ net primary production (NPP) from the ${ }^{13} \mathrm{C}$ tracer during the Indian scientific expedition to the Southern Ocean (February to April 2009). Scatter plots between in situ NPP and (b) VGPM, (c) Eppley-VGPM, and (d) CbPM NPP estimations. NPP: net primary production; CbPM: carbon-based productivity model; VGPM: vertically generalized production model.

trients to the sea surface have an important role in the formation of phytoplankton bloom. In order to examine the role of oceanic processes, we used satellite-derived physical oceanographic data as shown in Fig. 4.

Analysis of monthly SSHA and corresponding geostrophic currents showed the presence of a large cyclonic eddy with a diameter of $\sim 220 \mathrm{~km}$ in the vicinity of the MR seamount during September 2017 (Fig. 4d). The center of the cyclonic eddy was located at approximately $3.84^{\circ} \mathrm{E}$ and $64.47^{\circ} \mathrm{S}$, closely matching with the center of the polynya having warm $\operatorname{SST}\left(-1.35^{\circ} \mathrm{C}\right)$ compared to the peripheral cold SST of $-1.79^{\circ} \mathrm{C}$ (Fig. $4 \mathrm{~d}, \mathrm{~m}$ ). The polynya extent was nearly static from September to October. During November, the polynya expanded southeastward in conjunction with the movement of cyclonic eddy accompanied by a pool of warm SST and the phytoplankton bloom (Figs. 1c; 4f, o). The eddy was located at approximately $3.96^{\circ} \mathrm{E}$ and $66.5^{\circ} \mathrm{S}$ in November. Even though a dipole structure of cyclonic and anticyclonic eddies was observed in the polynya, a large cyclonic eddy dominated the flow pattern. The location of the cyclonic eddy matches well with the annular halo of warm SST and patch of phytoplankton bloom in the polynya (Figs. $1 \mathrm{~b}-\mathrm{c} ; 4 \mathrm{~d}-\mathrm{f}, 4 \mathrm{~m}-\mathrm{o}$ ). In addition, we find that the polynya surface was associated with persistent negative wind stress curl (Fig. 4g-i) that induced upwelling of subsurface water to the sea surface during September-November 2017 (Fig. 4j-1). Generally, the water column on the MR seamount is characterized by the presence of a cold fresh layer in the upper ocean separated from a lower warm saline layer by a weak pycnocline (Jena 
Table 2. Net primary production and bio-optical parameters during the occurrence of the Maud Rise polynya in October and November 2017. Values for November 2017 are given within brackets. NPP: net primary production; Chl $a$ : chlorophyll $a$; Eu: euphotic depth; PAR: photosynthetically available radiation; Kd: diffuse attenuation coefficient for downwelling irradiance; SST: sea surface temperature.

\begin{tabular}{|c|c|c|c|c|}
\hline & Minimum & Maximum & Mean & Standard deviation \\
\hline $\mathrm{NPP}\left(\mathrm{mg} \mathrm{C} \mathrm{m}^{-2} \mathrm{~d}^{-1}\right)$ & $60.08(101.43)$ & 374.07 (415.08) & $169.51(208.44)$ & $84.04(50.90)$ \\
\hline Chl $a\left(\mathrm{mg} \mathrm{m}^{-3}\right)$ & $0.07(0.06)$ & $3.48(4.67)$ & $0.29(0.28)$ & $0.26(0.20)$ \\
\hline $\mathrm{Eu}(\mathrm{m})$ & $27.12(8.35)$ & $84.24(109.56)$ & $53.72(56.90)$ & $13.59(12.49)$ \\
\hline PAR (einstein $\mathrm{m}^{-2} \mathrm{~d}^{-1}$ ) & $6.27(13.80)$ & $36.10(61.90)$ & $17.79(31.43)$ & $6.86(8.21)$ \\
\hline $\mathrm{Kd} 490\left(\mathrm{~m}^{-1}\right)$ & $0.03(0.02)$ & $0.39(0.37)$ & $0.06(0.06)$ & $0.03(0.02)$ \\
\hline $\operatorname{SST}\left({ }^{\circ} \mathrm{C}\right)$ & $-1.80(-1.80)$ & $-1.25(-1.31)$ & $-1.67(-1.65)$ & $0.12(0.14)$ \\
\hline
\end{tabular}

Table 3. Net primary production $\left(\mathrm{mg} \mathrm{C} \mathrm{m}^{-2} \mathrm{~d}^{-1}\right)$ for some coastal polynyas around Antarctica in November 2017. The values in the parentheses indicate locational information.

\begin{tabular}{lrrrr}
\hline & Minimum & Maximum & $\begin{array}{r}\text { Mean } \\
\text { dandard } \\
\text { deviation }\end{array}$ \\
\hline Amundsen Bay, Enderby Land & $34.3\left(66.75^{\circ} \mathrm{S}, 50.25^{\circ} \mathrm{E}\right)$ & $55.9\left(67.08^{\circ} \mathrm{S}, 50.58^{\circ} \mathrm{E}\right)$ & 44.7 & 6.5 \\
Barrier, Prydz Bay & $161.8\left(67.08^{\circ} \mathrm{S}, 79.25^{\circ} \mathrm{E}\right)$ & $505.5\left(67.08^{\circ} \mathrm{S}, 80.25^{\circ} \mathrm{E}\right)$ & 308.5 & 93.2 \\
Vincennes Bay & $53.17\left(66.83^{\circ} \mathrm{S}, 108.83^{\circ} \mathrm{E}\right)$ & $68.9\left(66.91^{\circ} \mathrm{S}, 108.66^{\circ} \mathrm{E}\right)$ & 61.5 & 5.3 \\
Wrigley Gulf, Amundsen Sea & $52.5\left(73.33^{\circ} \mathrm{S}, 125.66^{\circ} \mathrm{W}\right)$ & $74.0\left(73.41^{\circ} \mathrm{S}, 125.58^{\circ} \mathrm{W}\right)$ & 67.2 & 6.8 \\
Sulzberger Bay, Ross Sea & $251.9\left(75.91^{\circ} \mathrm{S}, 154.33^{\circ} \mathrm{W}\right)$ & $911.9\left(76.08^{\circ} \mathrm{S}, 155.33^{\circ} \mathrm{W}\right)$ & 606.6 & 143.8 \\
\hline
\end{tabular}

et al., 2019; de Steur et al., 2007). The combined influence of the cyclonic eddy and negative wind stress curl brings up the warm thermocline water into the sea surface through Ekman upwelling, resulting in a pool of warm SST at the polynya center (Fig. 4m-o). A depth-latitude cross section of the Copernicus Marine Environment Monitoring Service (CMEMS) global analysis and forecast data on potential temperature data at a polynya location (along $4.7^{\circ} \mathrm{E}$ ) provided evidence that the subsurface warm water was ventilated and brought closer to the upper ocean from the thermocline (upward doming of isotherms) from September through November 2017 (Jena et al., 2019). The Argo float located at the edge of the polynya also provided evidence on the uplift of thermocline during September 2017 (Fig. 6a). Ocean upwelling is known to supply dissolved iron to the upper ocean (Klunder et al., 2014; Rosso et al., 2014), preferably at the shallow bathymetry of less than $1 \mathrm{~km}$ at the MR seamount (Graham et al., 2015). Synchronously, along with the availability of light in October and November, the observed mechanism triggered a bloom condition in the MR polynya (Figs. 1b-c; $2 \mathrm{a}-\mathrm{c}$ ). The Argo float indicated mixed-layer warming on the Maud Rise during spring 2016 and 2017 (Fig. 6). The upwelling of high saline and warm water into the mixed layer facilitated the sea ice melting. The melting of sea ice leads to the development of a shallow mixed layer due to the accumulation of freshwater in the upper ocean. Therefore, we observed lower values of salinity in the mixed layer with increased stability of the water column (Fig. 6). The development of the shallow mixed layer improved the light availability in the upper ocean, and the condition was favorable for the growth of phytoplankton. Even though the Ekman upwelling was evident in September, the bloom did not appear in the polynya region under low light conditions of up to 12.6 einstein $\mathrm{m}^{-2} \mathrm{~d}^{-1}$. However, the bloom appeared in October-November 2017 under the influence of Ekman upwelling and improved light conditions of up to 36.1 and 61.9 einstein $\mathrm{m}^{-2} \mathrm{~d}^{-1}$ for October and November, respectively (Table 2). Analysis of net shortwave radiation data shows the record highest gain of values in the polynya region during SeptemberNovember 2017, considering the 38-year time series from 1979 through 2016 (Fig. 7). The observed anomalous gain in net shortwave radiation is possibly due to the early loss of sea ice cover.

Computation of NPP using the Eppley-VGPM model indicated the carbon fixation rates in the MR polynya varied between 60.08 and $374.07 \mathrm{mg} \mathrm{C} \mathrm{m}^{-2} \mathrm{~d}^{-1}$, with an average value of $169.51 \mathrm{mg} \mathrm{C} \mathrm{m}^{-2} \mathrm{~d}^{-1}$ for October 2017 (Table 2). The NPP increased in November and ranged from 101.43 to $415.08 \mathrm{mg} \mathrm{C} \mathrm{m}^{-2} \mathrm{~d}^{-1}$, averaging $208.44 \mathrm{mg} \mathrm{C} \mathrm{m}^{-2} \mathrm{~d}^{-1}$, with the highest rate being observed at $5.16^{\circ} \mathrm{E}$ and $66.58^{\circ} \mathrm{S}$. The observed values in the polynya remained within the previously reported range for the Polar Frontal Zone of the SO (100-6000 $\mathrm{m} \mathrm{C} \mathrm{m}^{-2} \mathrm{~d}^{-1}$ ) (Hoppe et al., 2017; Korb and Whitehouse, 2004; Mitchell and Holm-Hansen, 1991; Moore and Abbott, 2000; Park et al., 2010). The results from Aqua MODIS observations in the Antarctic coastal polynyas indicated that the NPP values ranged from 34.3 to $911.9 \mathrm{mg} \mathrm{C} \mathrm{m}^{-2} \mathrm{~d}^{-1}$ during November 2017 , with the highest rate being observed at the Sulzberger Bay polynya (Ross 
September

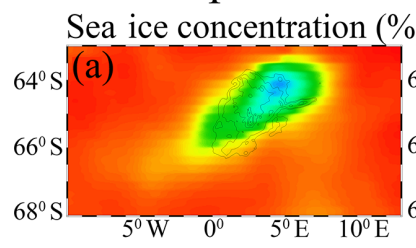

October

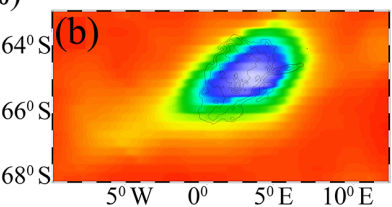

November

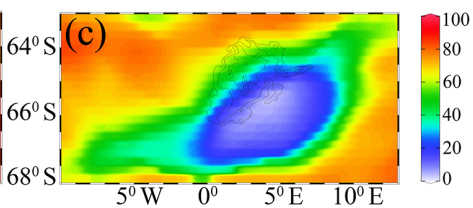

Sea surface height anomaly $(\mathrm{cm})$
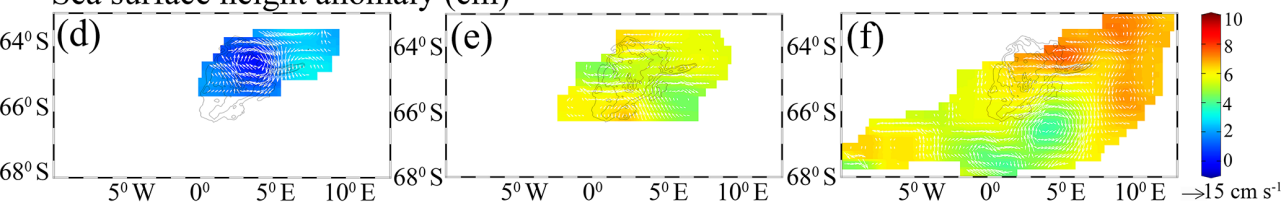

Wind stress curl $\times 10^{5}\left(\mathrm{~Pa} \mathrm{~m}^{-1}\right)$
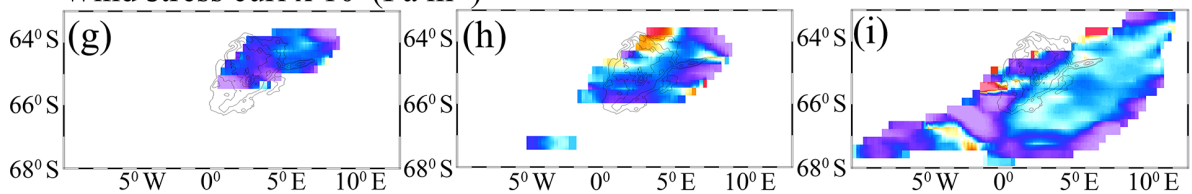

Upwelling index $\times 10^{5}\left(\mathrm{~m} \mathrm{~s}^{-1}\right)$
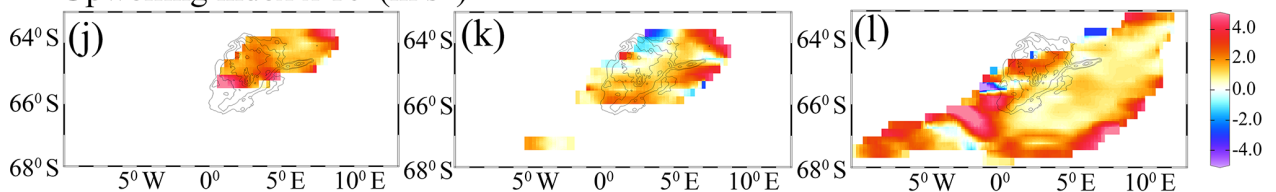

Sea surface temperature $\left({ }^{\circ} \mathrm{C}\right)$
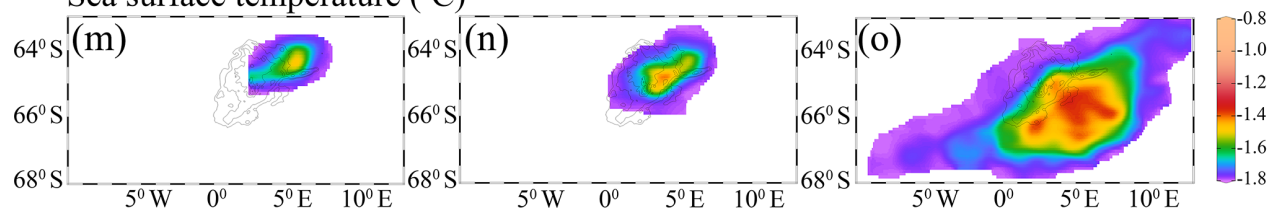

Figure 4. Monthly maps show (a-c) sea ice concentration, (d-f) sea surface height anomaly and geostrophic current velocity (white arrows), $(\mathbf{g}-\mathbf{i})$ wind stress curl, $(\mathbf{j}-\mathbf{l})$ upwelling index, and $(\mathbf{m}-\mathbf{0})$ sea surface temperature variability during the appearance of polynya from September to November 2017.

Sea) at $155.33^{\circ} \mathrm{W}$ and $76.08^{\circ} \mathrm{S}$ (Table 3). The NPP values in the MR polynya remained within the range of similar values observed for the coastal polynyas. The NPP values varied from 90 to $760 \mathrm{mg} \mathrm{C} \mathrm{m}^{-2} \mathrm{~d}^{-1}$ for 37 coastal polynyas around Antarctica (Arrigo and Dijken, 2003). Even though the phytoplankton bloom appeared in the MR polynya with NPP values similar to those of coastal polynyas, the spatial variation in NPP did not always follow the same pattern of chl $a$ (Fig. 1c, f). The observed pattern has been attributed to the effect of phytoplankton pigment composition and packaging (Bricaud et al., 2004; Ciotti et al., 2002; Jena, 2017; Lohrenz et al., 2003; Marra et al., 2007; Morel and Bricaud, 1981). The primary production in the upper ocean is a function of chl $a$, availability of light, nutrients, phytoplanktonspecific absorption coefficient (capacity of light absorption), and efficiency of phytoplankton to convert the absorbed light for carbon fixation (Behrenfeld and Falkowski, 1997a). However, the capacity of light absorption and the quantum yield of photosynthetic carbon fixation vary from one phytoplank- ton community to another (Claustre et al., 2005). Although the primary production in the Antarctic coastal polynyas is known to be dominated by prymnesiophytes (Phaeocystis antarctica) or diatoms (Arrigo et al., 2008b), the data on the phytoplankton community structure and their spectral characteristics are not available for the analysis in order to quantify the rate of carbon fixation for individual communities.

Further, Argo data were utilized to find the linkage between the observed bloom and the ocean $p \mathrm{CO}_{2}$ conditions. Analysis of Argo data indicated low $p \mathrm{CO}_{2}$ values that reached as low as $372.8 \mu \mathrm{atm}$ (Fig. 5d), corresponding to the occurrence of bloom during October-November 2017 (Fig. 5a). The $p \mathrm{CO}_{2}$ values declined during the occurrence of bloom in comparison with the period of non-bloom conditions in August-September 2017, 2015, and 2016 (Fig.5). The coefficient of correlation $(r)$ between the $p \mathrm{CO}_{2}$ and chl $a$ was $-0.56(p<0.01)$ during August-September 2017 (Fig. 8a). The relationship improved $(r=-0.82, p<0.01)$ and the spatial pattern closely matched during the bloom con- 

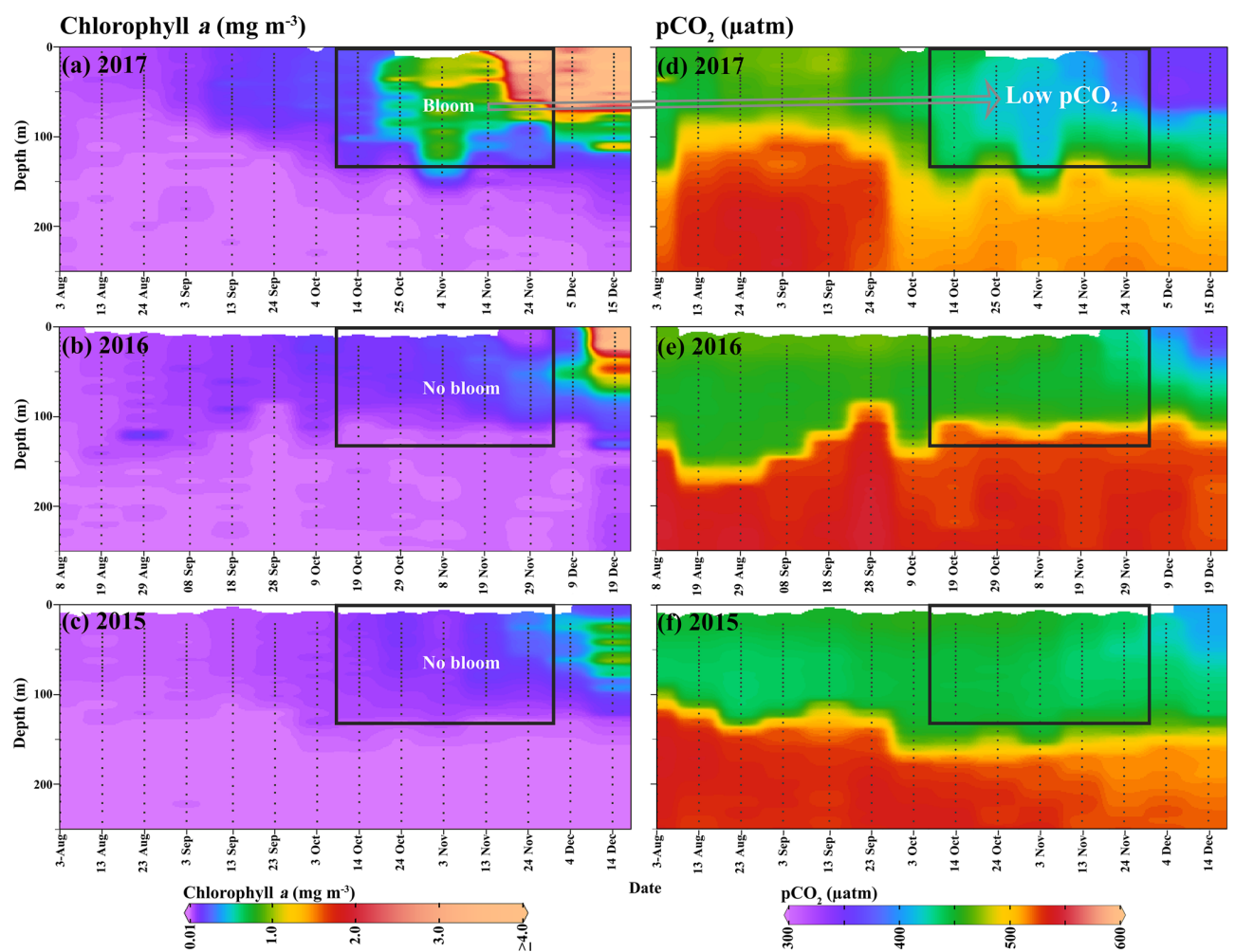

Figure 5. An Argo float (ID-5904468) located on the Maud Rise seamount shows profiles of (a-c) chlorophyll $a$ and $(\mathbf{d}-\mathbf{f}) p \mathrm{CO}_{2}$ from August to December (2015-2017). The marked rectangle in (a) shows the bloom condition from October to November 2017, and the bloom was absent during the 2 preceding years (2015 and 2016). Low $p \mathrm{CO}_{2}$ values were observed, corresponding to the bloom occurrence.
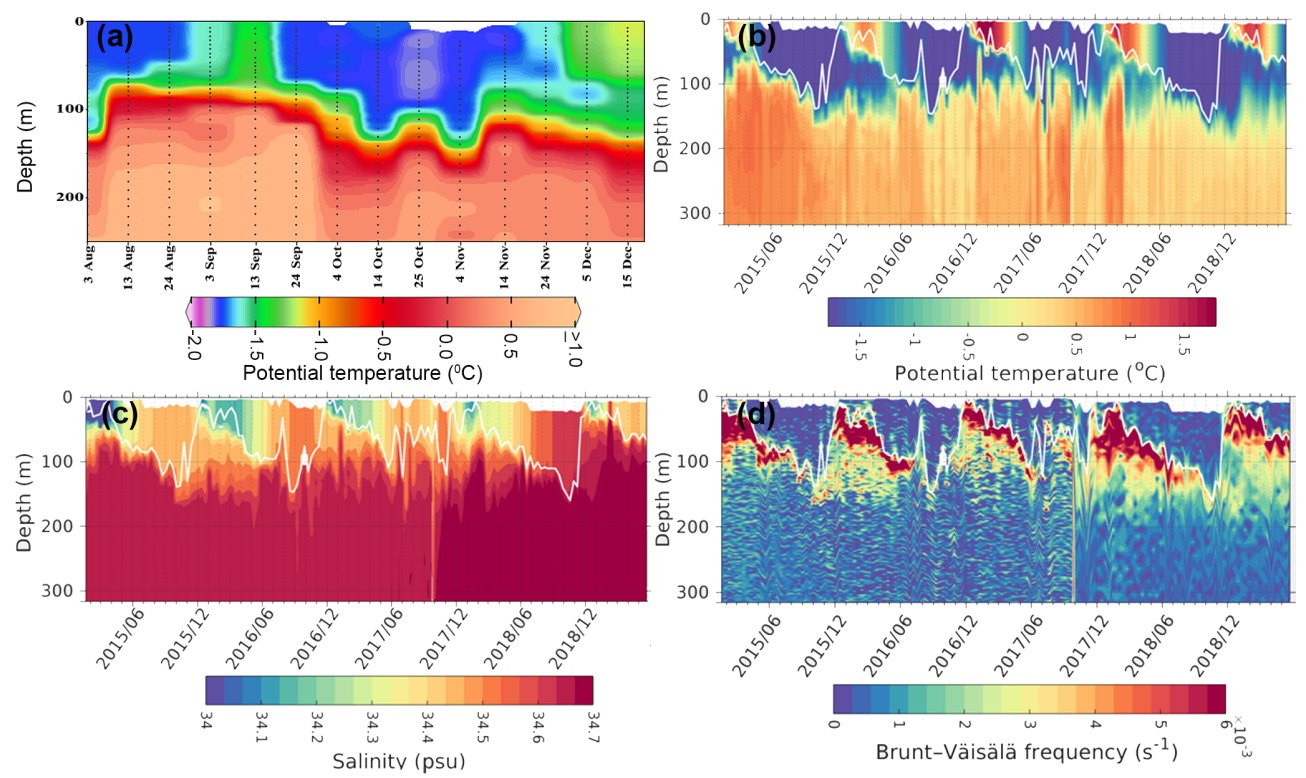

Figure 6. Profiles from an Argo float ID 5904468 located at the edge of the Maud Rise polynya show (a) potential temperature during August-December 2017, (b) potential temperature during 2015-2019, (c) salinity, and (d) static stability. The white solid line shows the variability of mixed-layer depth. The mixed layer was computed as the uppermost level of uniform potential density $(\sigma \theta)$ at the depth where the density in the upper level varies by $0.01 \mathrm{~kg} \mathrm{~m}^{-3}$ with respect to the surface (Kaufman et al., 2014). 


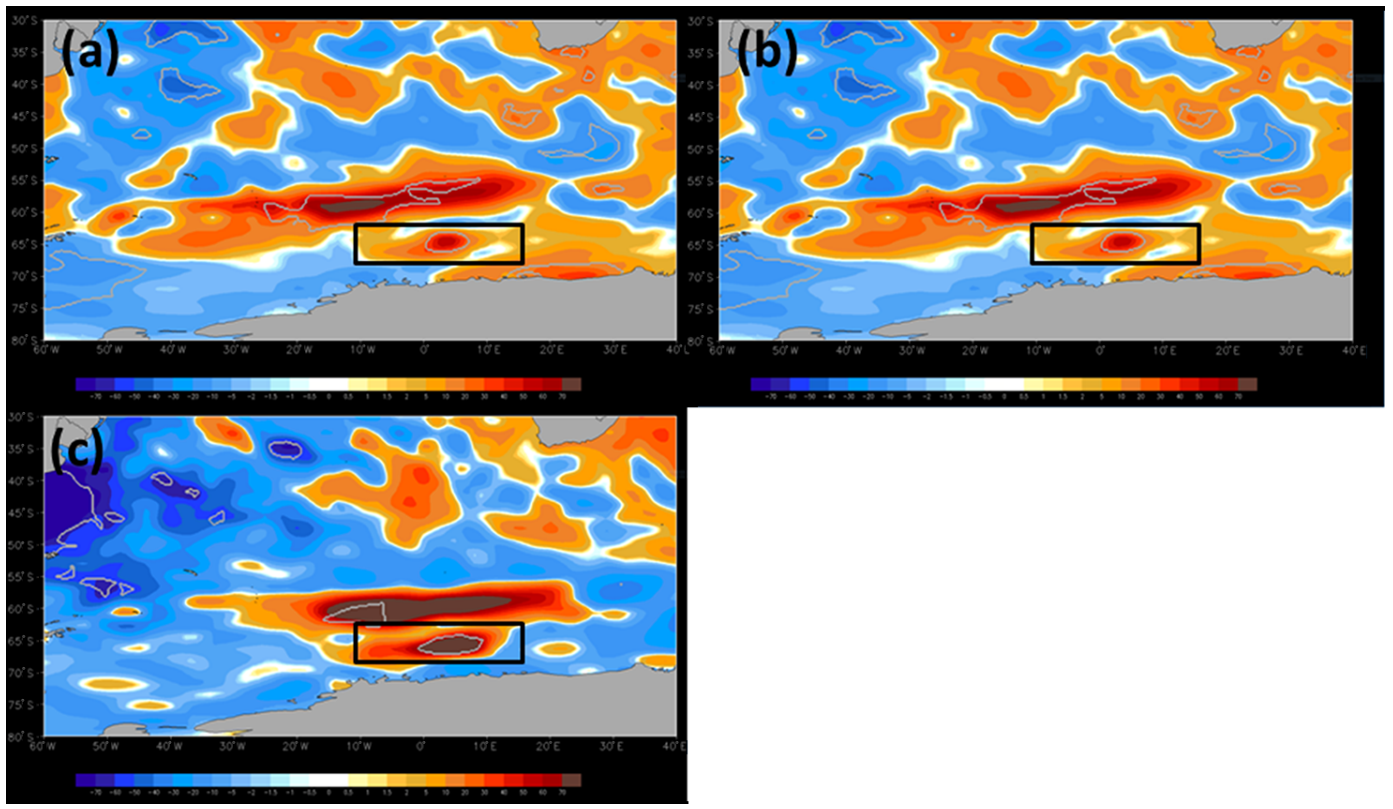

Figure 7. Monthly anomalies of net shortwave radiation $\left(\mathrm{W} \mathrm{m}^{-2}\right.$ ) for (a) September, (b) October, and (c) November 2017 in the Maud Rise polynya (black rectangles). The anomalies were computed relative to a 38-year climatology (1979-2016). The regions within grey polylines show the record level shortwave radiation in 2017 that lies outside of values from 1979 to 2016 .
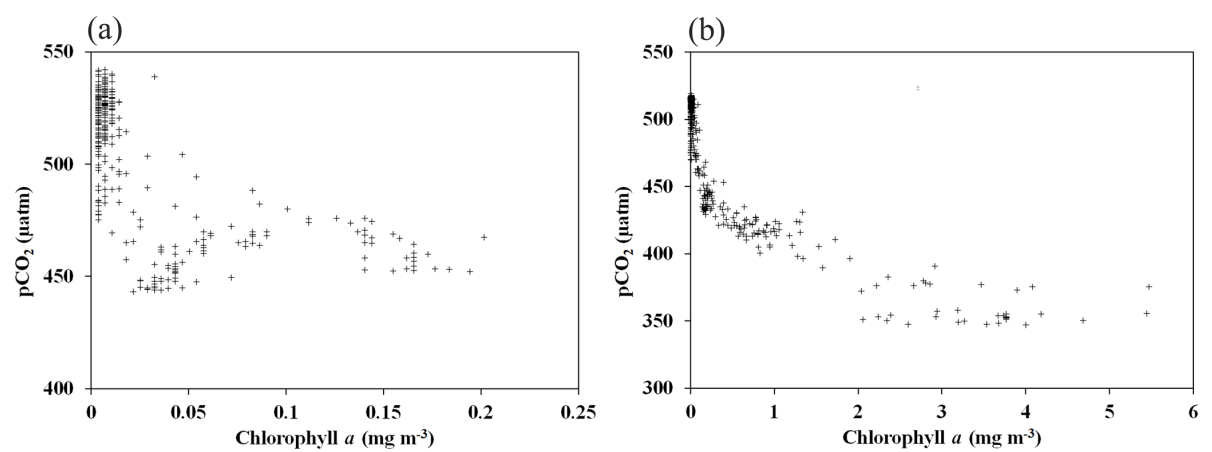

Figure 8. Argo data were utilized to find the relationship between the chlorophyll $a$ and the oceanic $p \mathrm{CO}_{2}$ conditions. (a) The coefficient of correlation $(r)$ between the $p \mathrm{CO}_{2}$ and chl $a$ was found to be $-0.56(p<0.01)$ during August-September 2017. (b) The relationship improved $(r=-0.82, p<0.01)$ during the bloom conditions in October-November 2017.

ditions in October-November 2017 (Figs. 8b, 5a-d). The best relationship was observed between the $p \mathrm{CO}_{2}$ and chl $a$ when the data were $\log$ transformed $(r=-0.94, p<0.01)$. The observed low $p \mathrm{CO}_{2}$ values in the polynya were likely due to the presence of chl $a$ bloom with high NPP, which has the potential to drive $\mathrm{CO}_{2}$ fluxes from the atmosphere to the ocean after forming a pressure gradient. This biological pumping process in the polynya could play an important role in lowering the atmospheric $\mathrm{CO}_{2}$ through transferring atmospheric $\mathrm{CO}_{2}$ to the ocean and subsequently into the ocean sediments. However, it is important to mention that the air-sea exchange of $\mathrm{CO}_{2}$ is driven by the $p \mathrm{CO}_{2}$ gradient, solubility of $\mathrm{CO}_{2}$ in the seawater (function of ocean temperature and salinity), and gas transfer velocity (function of wind speed and SST)
(Williams et al., 2017). Follow-up research is required in the future to quantify the contribution from physical and biological processes in the air-sea exchange of $\mathrm{CO}_{2}$ in the MR polynya and its likely role in regulating the global climate (Gordon and Comiso, 1988; Li et al., 2016).

\section{Summary and conclusion}

In this article, we have shown that the phytoplankton bloom occurred on the MR seamount during the appearance of the polynya in spring 2017. Analysis of multi-sensor satellite data from CZCS, SeaWiFS, MODIS, and VIIRS indicated that the bloom appeared for the first time in the satellite records since 1978. Since there is no previous report of its 
(a) Annual sea ice area and extent

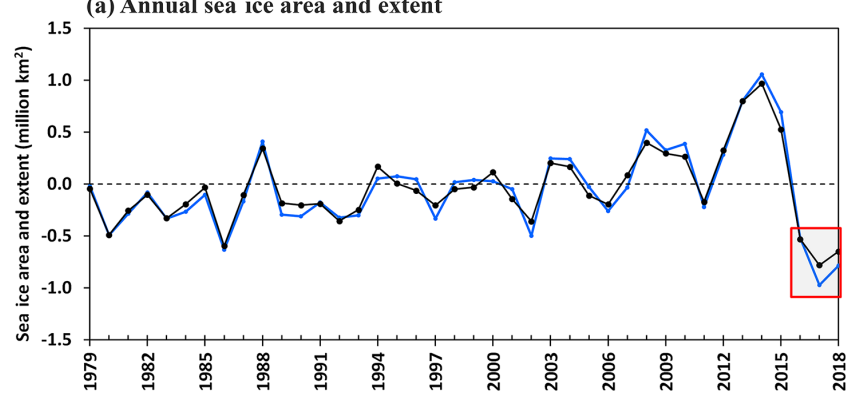

(b) Monthly sea ice extent
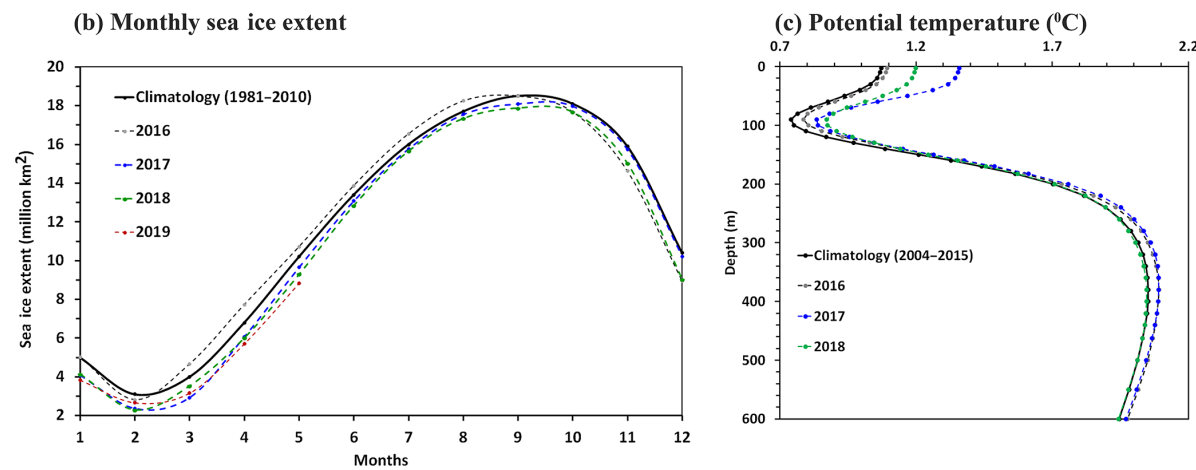

Figure 9. (a) Interannual variability of the Antarctic sea ice area (black) and extent (blue) anomaly relative to the climatology (1979-2015), as analyzed from satellite observations of passive microwave sensors. The red rectangle shows the anomalous record lowest sea ice area and extent observed for 3 successive years from 2016 to 2018, with the maximum melting occurring in 2017. (b) Monthly mean sea ice extent data indicated loss of sea ice that started from September 2016 and continued for the years 2017, 2018, and 2019. (c) Argo-based ocean potential temperature data (2004-2018) indicated anomalous upper ocean warming of the Southern Ocean from 2016 to 2018 . The potential temperature was spatially averaged over the south of the $55^{\circ} \mathrm{S}$ region encircling Antarctica.
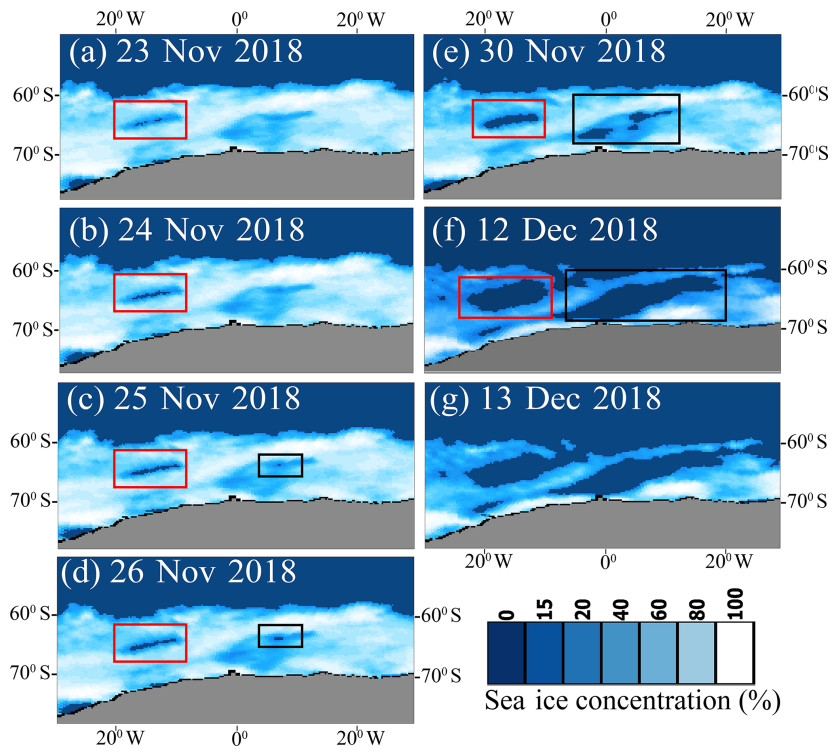

Figure 10. The Special Sensor Microwave Imager/Sounder (SSMIS) shows the reappearance of the Weddell Sea (red rectangle) and Maud Rise (black rectangle) polynyas from 23 November 2018 to 12 December 2018. The polynya disappeared on 13 December 2018 . occurrence in the MR polynya, we have examined additional data from the Argo float for firm evidence. The ARGO float located at the northwestern edge of the polynya provided evidence of bloom conditions from October to November 2017 compared to the preceding years of 2015 and 2016 when the sea ice was covered at the surface with low $\operatorname{chl} a$. We find that the combined influence of seamount and physical processes is responsible for the formation of the observed bloom. The presence of a seamount on the MR leads to uplift of thermocline and nutrient-enriched deep water that could fertilize the upper ocean through the upwelling process. During the austral winter and spring 2017, the supply of nutrients to the upper ocean arises through Ekman upwelling driven by a large cyclonic ocean eddy and persistent negative wind stress curl. Even though the Ekman upwelling was evident in September 2017, the bloom did not appear in the polynya due to prevailing low irradiance as expected in an austral winter. However, the bloom appeared in austral spring (OctoberNovember 2017) under the influence of Ekman upwelling and improved light conditions that favored the phytoplankton photosynthesis and growth. Low $p \mathrm{CO}_{2}$ conditions prevailed in the polynya due to the presence of chl $a$ bloom with high NPP that can lead to sinking of atmospheric $\mathrm{CO}_{2}$ fluxes into the ocean. The observed phytoplankton bloom reported 
in this article has large importance for the HNLC status of the SO.

Studies have shown intensification of polar cyclone activities due to the poleward shifting of the extratropical cyclone track in the background of a warming climate condition (Francis et al., 2019; Fyfe, 2003). As the polar cyclones are known to trigger the occurrence of polynyas (Francis et al., 2019; Jena et al., 2019; Turner et al., 2017) (through advection of moist, warm air from the extratropics, and sea ice divergence), the frequency of polynya events is likely to increase in the future (including over the MR) under a warming climate condition. The likelihood for the occurrence of the polynya is quite high with a background of anomalous upper ocean warming and sea ice loss, similar to the events that occurred in the Antarctic sea ice from 2016 to 2019 (Fig. 9). Indeed, the Weddell Sea and MR polynya reappeared in 23 November 2018 and lasted till 12 December 2018 as observed from SSMIS (Fig. 10). With the frequent reoccurrence of polynyas on the MR, the associated physical processes could possibly modify the region into a productive environment and likely have an impact on the regional ecosystem and carbon cycle. The occurrence of polynya and phytoplankton blooms in the MR may turn it into a potential sink of atmospheric $\mathrm{CO}_{2}$ through biological pumping and can be a major source of carbon and energy for the regional food web. The spatial dimension of the bloom in a polynya might be small; however, it is necessary to monitor and understand many important features of the Antarctic marine ecosystem in order to understand its complete role in the global biogeochemical cycle. The study demonstrates how the phytoplankton in the Southern Ocean (specifically over the shallow bathymetric region) would likely respond in the future under a warming climate condition and continued melting of Antarctic sea ice.

Code and data availability. We have analyzed monthly sea ice concentration (SIC) data (September to November 2017) from the passive microwave sensors with spatial resolution of $25 \mathrm{~km} \mathrm{ac}-$ quired from the National Snow and Ice Data Center (NSIDC) (data ID G02135, version 3, https://nsidc.org/data, last access: 21 March 2020; National Snow and Ice Data Center, 2020). The data were generated using the NASA Team algorithm, which converts satellite-derived brightness temperatures to gridded SIC (Cavalieri et al., 1997). We used ocean potential temperature data from the global marine Argo atlas (http://www.argo.ucsd.edu/Marine_Atlas. html, last access: 21 March 2020; Argo, 2020a) that indicated anomalous upper ocean warming of the Southern Ocean from 2016 to 2018. In order to analyze the Aqua-MODIS-derived net primary production (NPP), we have validated three ocean-color-based models, the vertically generalized production model (VGPM), EppleyVGPM, and carbon-based productivity model (CbPM), for selecting the best model for the study region. The model-based NPP values were available on a weekly timescale with a spatial resolution of $\sim$ $4 \mathrm{~km}$ (https://www.science.oregonstate.edu/ocean.productivity, last access: 21 March 2020; Ocean Productivity - Oregon State Uni- versity, 2020). The Argo data were generated from the Southern Ocean Carbon and Climate Observations and Modeling (SOCCOM) project by the National Science Foundation, Division of Polar Programs (NSF PLR-1425989), supplemented by NASA and by the international Argo program and the NOAA program. The data are available at https://www.mbari.org/science/, last access: 21 March 2020; Monterey Bay Aquarium Research Institute-Argo, 2020, http://www.argo.ucsd.edu/, last access: 21 March 2020; Argo, 2020b, http://argo.jcommops.org/, last access: 21 March 2020; Joint Technical Commission for Oceanography and Marine Meteorology in situ Observations Programme Support Centre, 2020. The primary production data used for the validation are available at https://data.mendeley.com/, last access: 21 March 2020, data repository under https://doi.org/10.17632/k438knz9zs.5 (Jena and Anil Kumar, 2020).

Author contributions. All works were carried out by BJ except the validation experiment of ocean color data using in situ observations from the Southern Ocean expeditions. NAK performed validation of ocean color data using in situ observations from the Southern Ocean expeditions and helped revise the manuscript.

Competing interests. The authors declare that they have no conflict of interest.

Acknowledgements. The authors are thankful to M. Ravichandran, director of NCPOR, for his continuous support. The authors greatly acknowledge various organizations such as the National Snow and Ice Data Center (NSIDC), National Oceanic and Atmospheric Administration (NOAA), National Aeronautics and Space Administration (NASA) Goddard Space Flight Center (Ocean Biology Processing Group), and their data processing teams for making various datasets available in their portals. Argo data were available from the Southern Ocean Carbon and Climate Observations and Modeling (SOCCOM) project funded by the National Science Foundation, Division of Polar Programs (NSF PLR-1425989), supplemented by NASA and by the international Argo program and the NOAA program (http://www.argo.ucsd.edu, http://argo.jcommops.org, last access: 21 March 2020). We also acknowledge Naveen Gandhi, IITM, for providing the in situ primary production data. This is NCPOR contribution J-70/2019-20.

Financial support. This research is supported by the Ministry of Earth Sciences and NCPOR.

Review statement. This paper was edited by Ted Maksym and reviewed by two anonymous referees.

\section{References}

Alderkamp, A.-C., Mills, M. M., van Dijken, G. L., Laan, P., Thuróczy, C.-E., Gerringa, L. J. A., de Baar, H. J. W., Payne, 
C. D., Visser, R. J. W., Buma, A. G. J., and Arrigo, K. R.: Iron from melting glaciers fuels phytoplankton blooms in the Amundsen Sea (Southern Ocean): Phytoplankton characteristics and productivity, Deep Sea Res. Part II, 71-76, 32-48, https://doi.org/10.1016/j.dsr2.2012.03.005, 2012.

Ardelan, M. V., Holm-Hansen, O., Hewes, C. D., Reiss, C. S., Silva, N. S., Dulaiova, H., Steinnes, E., and Sakshaug, E.: Natural iron enrichment around the Antarctic Peninsula in the Southern Ocean, Biogeosciences, 7, 11-25, https://doi.org/10.5194/bg-711-2010, 2010.

Argo: Global Marine Argo Atlas, available at: http://www.argo. ucsd.edu/Marine_Atlas.html, last access: 21 March 2020a.

Argo: part of the integrated global observation strategy, http://www. argo.ucsd.edu/, last access: 21 March 2020.

Arrigo, K. R. and Alderkamp, A.-C.: Shedding dynamic light on Fe limitation (DynaLiFe), Deep Sea Res. Pt. II, 71-76, 1-4, https://doi.org/10.1016/j.dsr2.2012.03.004, 2012.

Arrigo, K. R. and van Dijken, G. L.: Phytoplankton dynamics within 37 Antarctic coastal polynya systems, J. Geophys. Res., 108, 3271, https://doi.org/10.1029/2002jc001739, 2003.

Arrigo, K. R., van Dijken, G., and Long, M.: Coastal Southern Ocean: A strong anthropogenic $\mathrm{CO}_{2}$ sink, Geophys. Res. Lett., 35, L21602, https://doi.org/10.1029/2008GL035624, 2008a.

Arrigo, K. R., van Dijken, G. L., and Bushinsky, S.: Primary production in the Southern Ocean, 1997-2006, J. Geophys. Res.Oceans, 113, C08004, https://doi.org/10.1029/2007JC004551, 2008 b.

Bates, N. R., Hansell, D. A., Carlson, C. A., and Gordon, L. I.: Distribution of $\mathrm{CO}_{2}$ species, estimates of net community production, and air-sea $\mathrm{CO}_{2}$ exchange in the Ross Sea polynya, J. Geophys. Res.-Oceans, 103, 2883-2896, https://doi.org/10.1029/97JC02473, 1998.

Behrenfeld, M. J. and Falkowski, P. G.: A consumer's guide to phytoplankton primary productivity models, Limnol. Oceanogr., 42, 1479-1491, https://doi.org/10.4319/lo.1997.42.7.1479, 1997a.

Behrenfeld, M. J. and Falkowski, P. G.: Photosynthetic rates derived from satellite-based chlorophyll concentration, Limnol. Oceanogr., 42, 1-20, https://doi.org/10.4319/lo.1997.42.1.0001, 1997b.

Boyd, P. W., Crossley, A. C., DiTullio, G. R., Griffiths, F. B., Hutchins, D. A., Queguiner, B., Sedwick, P. N., and Trull, T. W.: Control of phytoplankton growth by iron supply and irradiance in the subantarctic Southern Ocean: Experimental results from the SAZ Project, J. Geophys. Res.-Oceans, 106, 31573-31583, https://doi.org/10.1029/2000JC000348, 2001.

Bricaud, A., Babin, M., Morel, A., and Claustre, H.: Variability in the chlorophyll-specific absorption coefficients of natural phytoplankton: Analysis and parameterization, J. Geophys. Res., 100, 13321, https://doi.org/10.1029/95jc00463, 2004.

Cassar, N., Bender, M. L., Barnett, B. A., Fan, S., Moxim, W. J., Levy, H., and Tilbrook, B.: The Southern Ocean Biological Response to Aeolian Iron Deposition, Science, 317, 1067-1070, https://doi.org/10.1126/science.1144602, 2007.

Cavalieri, D. J., Parkinson, C. L., Gloersen, P., and Zwally, H. J.: Arctic and Antarctic Sea Ice Concentrations from Multichannel Passive-Microwave Satellite Data Sets: October 1978September 1995 - User's Guide, NASA TM 104647, Greenbelt, MD 20771, 1997.
Ciotti, Á. M., Lewis, M. R., and Cullen, J. J.: Assessment of the relationships between dominant cell size in natural phytoplankton communities and the spectral shape of the absorption coefficient, Limnol. Oceanogr., 47, 404-417, https://doi.org/10.4319/lo.2002.47.2.0404, 2002.

Claustre, H., Babin, M., Merien, D., Ras, J., Prieur, L., Dallot, S., Prasil, O., Dousova, H., and Moutin, T.: Toward a taxon-specific parameterization of bio-optical models of primary production: A case study in the North Atlantic, J. Geophys. Res.-Oceans, 110, C07S12, https://doi.org/10.1029/2004JC002634, 2005.

de Baar, H. J. W. and Boyd, P. M.: The Role of Iron in Plankton Ecology and Carbon Dioxide Transfer of the Global Oceans, in The Dynamic Ocean Carbon Cycle: A Midterm Synthesis of the Joint Global Ocean Flux Study, edited by: Hanson, R. B., Ducklow, H. W., and Field, J. G., 61-140, Cambridge University Press, 1999.

de Steur, L., Holland, D. M., Muench, R. D., and McPhee, M. G.: The warm-water "Halo" around Maud Rise: Properties, dynamics and Impact, Deep-Sea Res. Pt. I, 54, 871-896, https://doi.org/10.1016/j.dsr.2007.03.009, 2007.

Duce, R. A. and Tindale, N. W.: Atmospheric transport of iron and its deposition in the ocean, Limnol. Oceanogr., 36, 1715-1726, https://doi.org/10.4319/lo.1991.36.8.1715, 1991.

Eppley, R.: Temperature and phytoplankton growth in the sea, Fishery Bull., 70, 1063-1085, available at: http://lgmacweb.env.uea. ac.uk/green_ocean/publications/Nano/Eppley72.pdf (last access: 21 March 2020), 1972.

Fetterer, F., Knowles, K., Meier, W., and Savoie, M.: Sea Ice Index, Version 2 (updated daily), Boulder, Colorado USA, 2016.

Fitch, D. T. and Moore, J. K.: Wind speed influence on phytoplankton bloom dynamics in the Southern Ocean Marginal Ice Zone, J. Geophys. Res.-Oceans, 112, C08006, https://doi.org/10.1029/2006JC004061, 2007.

Francis, D., Eayrs, C., Cuesta, J., and Holland, D.: Polar Cyclones at the Origin of the Reoccurrence of the Maud Rise Polynya in Austral Winter 2017, J. Geophys. Res.-Atmos., 124, 5251-5267, https://doi.org/10.1029/2019JD030618, 2019.

Fyfe, J. C.: Extratropical Southern Hemisphere cyclones: Harbingers of climate change?, J. Climate, 16, 2802-2805, https://doi.org/10.1175/15200442(2003)016<2802:ESHCHO>2.0.CO;2, 2003.

Gall, M. P., Boyd, P. W., Hall, J., Safi, K. A., and Chang, H.: Phytoplankton processes. Part 1: Community structure during the Southern Ocean Iron RElease Experiment (SOIREE), Deep Sea Res. Pt. II, 48, 2551-2570, https://doi.org/10.1016/S09670645(01)00008-X, 2001.

Gandhi, N., Ramesh, R., Laskar, A. H., Sheshshayee, M. S., Shetye, S., Anilkumar, N., Patil, S. M., and Mohan, R.: Zonal variability in primary production and nitrogen uptake rates in the southwestern Indian Ocean and the Southern Ocean, Deep-Sea Res. Pt. I, 67, 32-43, https://doi.org/10.1016/j.dsr.2012.05.003, 2012.

Gordon, A. L. and Comiso, J. C.: Polynyas in the Southern Ocean the global heat engine that couples the ocean and the atmosphere, Sci. Am., 258, 90-97, 1988.

Graham, R. M., Boer, A. M. De, van Sebille, E., Kohfeld, K. E., and Schlosser, C.: Inferring source regions and supply mechanisms of iron in the Southern Ocean from satellite chlorophyll data, Deep Sea Res. Pt. I, 104, 9-25, https://doi.org/10.1016/j.dsr.2015.05.007, 2015. 
Hoppe, C. J. M., Wolf-Gladrow, D. A., Trimborn, S., Strass, V., Soppa, M. A., Cheah, W., Rost, B., Bracher, A., SantosEcheandia, J., Laglera, L. M., Hoppema, M., Klaas, C., and Ossebaar, S.: Controls of primary production in two phytoplankton blooms in the Antarctic Circumpolar Current, Deep Sea Res. Pt. II, 138, 63-73, https://doi.org/10.1016/j.dsr2.2015.10.005, 2017.

Jena, B.: Satellite remote sensing of the island mass effect on the Sub-Antarctic Kerguelen Plateau, Southern Ocean, Front. Earth Sci., 10, 479-486, https://doi.org/10.1007/s11707-016-0561-8, 2016.

Jena, B.: The effect of phytoplankton pigment composition and packaging on the retrieval of chlorophyll-a concentration from satellite observations in the Southern Ocean, Int. J. Remote Sens., 38, 3763-3784, https://doi.org/10.1080/01431161.2017.1308034, 2017.

Jena, B. and Anil Kumar, N.: Primary production data for the Indian Ocean sector of the Southern Ocean, Mendeley, https://doi.org/10.17632/k438knz9zs.5, 2020.

Jena, B., Ravichandran, M., and Turner, J.: Recent Reoccurrence of Large Open-Ocean Polynya on the Maud Rise Seamount, Geophys. Res. Lett., 46, 4320-4329, https://doi.org/10.1029/2018GL081482, 2019.

Johnson, K. S., Jannasch, H. W., Coletti, L. J., Elrod, V. A., Martz, T. R., Takeshita, Y., Carlson, R. J., and Connery, J. G.: Deep-Sea DuraFET: A Pressure Tolerant pH Sensor Designed for Global Sensor Networks, Anal. Chem., 88, 32493256, https://doi.org/10.1021/acs.analchem.5b04653, 2016.

Johnson, R., Strutton, P. G., Wright, S. W., McMinn, A., and Meiners, K. M.: Three improved satellite chlorophyll algorithms for the Southern Ocean, J. Geophys. Res.-Oceans, 118, 3694-3703, https://doi.org/10.1002/jgrc.20270, 2013.

Joint Technical Commission for Oceanography and Marine Meteorology in situ Observations Programme Support Centre: available at http://argo.jcommops.org/, last access: 21 March 2020.

Kahru, M., Mitchell, B. G., Gille, S. T., Hewes, C. D., and Holm-Hansen, O.: Eddies enhance biological production in the Weddell-Scotia Confluence of the Southern Ocean, Geophys. Res. Lett., 34, L14603, https://doi.org/10.1029/2007GL030430, 2007.

Kahru, M., Lee, Z., Mitchell, B. G., and Nevison, C. D.: Effects of sea ice cover on satellite-detected primary production in the Arctic Ocean, Biol. Lett., 12, 20160223 , https://doi.org/10.1098/rsbl.2016.0223, 2016.

Kaufman, D. E., Friedrichs, M. A. M., Smith, W. O., Queste, B. Y., Heywood, K. J., and Sea, R.: Deep-Sea Research I Biogeochemical variability in the southern Ross Sea as observed by a glider deployment, Deep-Sea Res. Pt. I, 92, 93-106, https://doi.org/10.1016/j.dsr.2014.06.011, 2014.

Klunder, M. B., Laan, P., De Baar, H. J. W., Middag, R., Neven, I., and Van Ooijen, J.: Dissolved Fe across the Weddell Sea and Drake Passage: impact of DFe on nutrient uptake, Biogeosciences, 11, 651-669, https://doi.org/10.5194/bg-11-651-2014, 2014.

Korb, R. E. and Whitehouse, M.: Contrasting primary production regimes around South Georgia, Southern Ocean: Large blooms versus high nutrient, low chlorophyll waters, Deep-Sea Res. Pt. I, 51, 721-738, https://doi.org/10.1016/j.dsr.2004.02.006, 2004.
Labrousse, S., Williams, G., Tamura, T., Bestley, S., Sallée, J.-B., Fraser, A. D., Sumner, M., Roquet, F., Heerah, K., Picard, B., Guinet, C., Harcourt, R., McMahon, C., Hindell, M. A., and Charrassin, J.-B.: Coastal polynyas: Winter oases for subadult southern elephant seals in East Antarctica, Sci. Rep., 8, 3183, https://doi.org/10.1038/s41598-018-21388-9, 2018.

Lannuzel, D., Schoemann, V., de Jong, J., Pasquer, B., van der Merwe, P., Masson, F., Tison, J.-L., and Bowie, A.: Distribution of dissolved iron in Antarctic sea ice: Spatial, seasonal, and interannual variability, J. Geophys. Res.-Biogeosci., 115, G03022, https://doi.org/10.1029/2009JG001031, 2010.

Li, Y., Ji, R., Jenouvrier, S., Jin, M., and Stroeve, J.: Synchronicity between ice retreat and phytoplankton bloom in circum-Antarctic polynyas, Geophys. Res. Lett., 43, 2086-2093, https://doi.org/10.1002/2016GL067937, 2016.

Lohrenz, S. E., Weidemann, A. D., and Tuel, M.: Phytoplankton spectral absorption as influenced by community size structure and pigment composition, J. Plankton Res., 25, 35-61, https://doi.org/10.1093/plankt/25.1.35, 2003.

Marra, J., Trees, C. C., and O'Reilly, J. E.: Phytoplankton pigment absorption: A strong predictor of primary productivity in the surface ocean, Deep-Sea Res. Pt. I, 54, 155-163, https://doi.org/10.1016/j.dsr.2006.12.001, 2007.

Mashayek, A., Ferrari, R., Merrifield, S., Ledwell, J. R., St Laurent, L., and Garabato, A. N.: Topographic enhancement of vertical turbulent mixing in the Southern Ocean, Nat. Commun., 8, 14197, https://doi.org/10.1038/ncomms14197, 2017.

Mitchell, B. G. and Holm-Hansen, O.: Observations of modeling of the Antartic phytoplankton crop in relation to mixing depth, Deep Sea Res. Pt. A, 38, 981-1007, https://doi.org/10.1016/0198-0149(91)90093-U, 1991.

Monterey Bay Aquarium Research Institute-Argo: available at: https://www.mbari.org/science, last access: 21 March 2020.

Moore, J. K. and Abbott, M. R.: Phytoplankton chlorophyll distributions and primary production in the Southern Ocean, J. Geophys. Res., 105, 28709-28722, https://doi.org/10.1029/1999JC000043, 2000.

Morel, A. and Bricaud, A.: Theoretical results concerning light absorption in a discrete medium, and application to specific absorption of phytoplankton, Deep Sea Res. Pt. A, 28, 1375-1393, https://doi.org/10.1016/0198-0149(81)90039-X, 1981.

Mu, L., Stammerjohn, S. E., Lowry, K. E., and Yager, P. L.: Spatial variability of surface $p \mathrm{CO}_{2}$ and air-sea $\mathrm{CO}_{2}$ flux in the Amundsen Sea Polynya, Antarctica, Elementa: Sci. Anthro., 2, 000036, https://doi.org/10.12952/journal.elementa.000036, 2014.

Muench, R. D., Morison, J. H., Padman, L., Martinson, D., Schlosser, P., Huber, B., and Hohmann, R.: Maud Rise revisited, J. Geophys. Res., 106, 2423-2440, https://doi.org/10.1029/2000JC000531, 2001.

National Snow and Ice Data Center: data ID G02135, version 3, available at: https://nsidc.org/data, last access: 21 March 2020.

Ocean Productivity - Oregon State University, available at: https:// www.science.oregonstate.edu/ocean.productivity, last access: 21 March 2020.

Park, J., Oh, I. S., Kim, H. C., and Yoo, S.: Variability of SeaWiFs chlorophyll-a in the southwest Atlantic sector of the Southern Ocean: Strong topographic effects and weak seasonality, Deep-Sea Res. Pt. I, 57, 604-620, https://doi.org/10.1016/j.dsr.2010.01.004, 2010. 
Parkinson, C. L.: A 40-y record reveals gradual Antarctic sea ice increases followed by decreases at rates far exceeding the rates seen in the Arctic, P. Natl. Acad. Sci. USA, 116, 14414-14423, https://doi.org/10.1073/pnas.1906556116, 2019.

Peck, L. S., Barnes, D. K. A., Cook, A. J., Fleming, A. H., and Clarke, A.: Negative feedback in the cold: Ice retreat produces new carbon sinks in Antarctica, Global Change Biol., 16, 26142623, https://doi.org/10.1111/j.1365-2486.2009.02071.x, 2010.

Planquette, H., Sherrell, R. M., Stammerjohn, S., and Field, M. P.: Particulate iron delivery to the water column of the Amundsen Sea, Antarctica, Mar. Chem., 153, 15-30, https://doi.org/10.1016/j.marchem.2013.04.006, 2013.

Pond, S. and Pickard, G. L.: Introductory Dynamical Oceanography, 2nd Edn., Butterworh-Heinemann Ltd., Oxford UK, 1983.

Pritchard, H. D., Arthern, R. J., Vaughan, D. G., and Edwards, L. A.: Extensive dynamic thinning on the margins of the Greenland and Antarctic ice sheets, Nature, 461, 971-975, https://doi.org/10.1038/nature08471, 2009.

Raiswell, R., Benning, L. G., Tranter, M., and Tulaczyk, S.: Bioavailable iron in the Southern Ocean: the significance of the iceberg conveyor belt, Geochem. Trans., 9, 1-9, https://doi.org/10.1186/1467-4866-9-7, 2008.

Reynolds, R. W. and Smith, T. M.: Improved global sea surface temperature analyses using optimum interpolation, J. Climate, 7, 929-948, https://doi.org/10.1175/15200442(1994)007<0929:IGSSTA>2.0.CO;2, 1994.

Roden, G. I.: Effect of Seamounts and Seamount Chains on Ocean Circulation and Thermohaline Structure, in: Seamounts, Islands, and Atolls, 335-354, American Geophysical Union (AGU), 2013.

Rosso, I., Hogg, A. M., Strutton, P. G., Kiss, A. E., Matear, R., Klocker, A., and van Sebille, E.: Vertical transport in the ocean due to sub-mesoscale structures: Impacts in the Kerguelen region, Ocean Modell., 80, 10-23, https://doi.org/10.1016/j.ocemod.2014.05.001, 2014.

Schofield, O., Miles, T., Alderkamp, A. C., Lee, S. H., Haskins, C., Rogalsky, E., Sipler, R., Sherrell, R., and Yager, P. L.: In situ phytoplankton distributions in the Amundsen Sea Polynya measured by autonomous gliders, Elementa, 3, 1-17, https://doi.org/10.12952/journal.elementa.000073, 2015.

Selph, K. E., Landry, M. R., Allen, C. B., Calbet, A., Christensen, S., and Bidigare, R. R.: Microbial community composition and growth dynamics in the Antarctic Polar Front and seasonal ice zone during late spring 1997, Deep Sea Res. Pt. II, 48, 40594080, https://doi.org/10.1016/S0967-0645(01)00077-7, 2001.

Shadwick, E. H., Tilbrook, B., and Currie, K. I.: Latesummer biogeochemistry in the Mertz Polynya: East Antarctica, J. Geophys. Res.-Oceans, 122, 7380-7394, https://doi.org/10.1002/2017JC013015, 2017.

Stirling, I.: The importance of polynas, ice edges, and leads to marine mammals and birds, J. Mar. Syst., 10, 9-21, https://doi.org/10.1016/S0924-7963(96)00054-1, 1997.

Strass, V. H., Garabato, A. C. N., Pollard, R. T., Fischer, H. I., Hense, I., Allen, J. T., Read, J. F., Leach, H., and Smetacek, V.: Mesoscale frontal dynamics: shaping the environment of primary production in the Antarctic Circumpolar Current, Deep Sea Res. Pt. II, 49, 3735-3769, https://doi.org/10.1016/S09670645(02)00109-1, 2002.
Tagliabue, A., Sallée, J.-B., Bowie, A. R., Lévy, M., Swart, S., and Boyd, P. W.: Surface-water iron supplies in the Southern Ocean sustained by deep winter mixing, Nat. Geosci., 7, 314, https://doi.org/10.1038/ngeo2101, 2014.

Tamura, T., Ohshima, K. I., and Nihashi, S.: Mapping of sea ice production for Antarctic coastal polynyas, Geophys. Res. Lett., 35, L07606, https://doi.org/10.1029/2007GL032903, 2008.

Turner, J., Phillips, T., Marshall, G. J., Hosking, J. S., Pope, J. O., Bracegirdle, T. J., and Deb, P.: Unprecedented springtime retreat of Antarctic sea ice in 2016, Geophys. Res. Lett., 44, 6868-6875, https://doi.org/10.1002/2017GL073656, 2017.

van der Merwe, P., Lannuzel, D., Bowie, A. R., Nichols, C. A. M., and Meiners, K. M.: Iron fractionation in pack and fast ice in East Antarctica: Temporal decoupling between the release of dissolved and particulate iron during spring melt, Deep Sea Res. Pt. II, 58, 1222-1236, https://doi.org/10.1016/j.dsr2.2010.10.036, 2011.

Wagener, T., Guieu, C., Losno, R., Bonnet, S., and Mahowald, N.: Revisiting atmospheric dust export to the Southern Hemisphere ocean: Biogeochemical implications, Global Biogeochem. Cy., 22, GB2006, https://doi.org/10.1029/2007GB002984, 2008.

Wåhlin, A. K., Yuan, X., Björk, G., and Nohr, C.: Inflow of Warm Circumpolar Deep Water in the Central Amundsen Shelf, J. Phys. Oceanogr., 40, 1427-1434, https://doi.org/10.1175/2010JPO4431.1, 2010.

Weijer, W., Veneziani, M., Stössel, A., Hecht, M. W., Jeffery, N., Jonko, A., Hodos, T., and Wang, H.: Local atmospheric response to an open-ocean polynya in a high-resolution climate model, J. Climate, 30, 1629-1641, https://doi.org/10.1175/JCLI-D-160120.1, 2017.

Westberry, T., Behrenfeld, M. J., Siegel, D. A., and Boss, E.: Carbon-based primary productivity modeling with vertically resolved photoacclimation, Global Biogeochem. Cy., 22, 1-18, https://doi.org/10.1029/2007GB003078, 2008.

White, M. and Mohn, C.: Review of Physical Processes at Seamounts, Oceanic Seamounts: An Integrated Study, University of Hamburg, 2002.

Williams, N. L., Juranek, L. W., Feely, R. A., Johnson, K. S., Sarmiento, J. L., Talley, L. D., Dickson, A. G., Gray, A. R., Wanninkhof, R., Russell, J. L., Riser, S. C., and Takeshita, Y.: Calculating surface ocean $p \mathrm{CO}_{2}$ from biogeochemical Argo floats equipped with $\mathrm{pH}$ : An uncertainty analysis, Global Biogeochem. Cy., 31, 591-604, https://doi.org/10.1002/2016GB005541, 2017.

Yager, S., Bertilsson, S., Lowry, K., Severmann, P., Schofield, O., Wilson, S., Stammerjohn, S., Moksnes, P.-O., Thatje, S., Riemann, L., van Dijken, G., Garay, L., Abrahamsen, P., Post, A., Ndungo, K., Alderkamp, A.-C., Guerrero, R., Sherrell, R., Randall-Goodwin, E., and Arrigo, K.: ASPIRE: The Amundsen Sea Polynya International Research Expedition, Oceanography, 25, 40-53, https://doi.org/10.5670/oceanog.2012.73, 2012.

Zanowski, H., Hallberg, R., and Sarmiento, J. L.: Abyssal Ocean Warming and Salinification after Weddell Polynyas in the GFDL CM2G Coupled Climate Model, J. Phys. Oceano., 45, 2755 2772, https://doi.org/10.1175/JPO-D-15-0109.1, 2015. 